\title{
The Impact of Purchasing Behaviour towards Digital Marketing in Kangar, Perlis
}

\author{
Syahirah Syuhada Sohibul Basr ${ }^{l}$, Ku Amir Ku Daud ${ }^{2}$ \\ School of Business Innovation and Technopreneurship, Universiti Malaysia Perlis, Malaysia
}

\begin{abstract}
Marketing activity through digital medium is becoming popular among the entrepreneurship. This have managed to influence the purchasing behavior of the citizens. However, there certain people who still doubting the use of technology in daily life. There also a few people whom still not confident in using technology. Thus, this purpose of this study is to research the impact of purchasing behavior toward digital marketing. Theory of planned behavior is use in this research to explain the independent variables, which is attitude, subjective norms, perceived behavior and pricing that effecting the purchasing behavior. Besides, descriptive analysis, correlation analysis and regression analysis are use analyze the significant of independent variables towards dependent variable. This study uses quantitative method and 381 sets of questionnaires are distributed around Kangar. Reliability test are conduct for 40 respondents and obtain Cronbach's Alpha 0.731, which is acceptable. Statistical Package for the Social Sciences (SPSS) is used to evaluate the data collected. Under regression analysis, this study find out that the attitude, subjective norms and pricing have an impact to digital marketing. While perceived behavior control has no significant to the dependent variable.
\end{abstract}

\section{Key words: Digital Marketing, Attitude, Subjective Norms, Perceived Behavior, Pricing, Purchasing Behavior}

\section{INTRODUCTION}

Digital marketing is one of the technologies in this era that have assist a lot of the marketer to promote their product, brand or service. This type of marketing covers all the marketing activity using the digital device and the internet. Via digital channels, marketing is being given control, tools and data to help them evaluate the campaign's effectiveness. Company use the digital platform such as social media, emails, search engine and others website to communicate with existing and potential clients. For example, now in most company there are a new position have introduce known as "social media admin" where their job is to manage the social media pages of the company. They need to create content regarding the product or service to draw attention of the customers. This will build brand awareness among people. The purchasing activities also shifting to accommodate the change. This is how marketing activity being affected.

Digital marketing also being separated into two which is online channel and offline channel. The primary difference would be that online channel were based entirely on Internet while the for offline activity, they only require device and not inevitably hooked up to the Internet By digitalize, the victual advertisement can possibly run 24/7 without any boundaries and can reach wider range of customers [17]. Most company like to use digital marketing because of the cost itself. The cost is affordable and much lower than traditional marketing. [32] stated that "You can easily plan a successful online marketing strategy within your budget by the use of digital marketing that offers an inexpensive technique in comparison to other advertising channels such as radio, TV and more."

Digital marketing consists of several type such as search engine optimization, pay per click advertisement, content marketing and social media platform. This type of marketing can grab the attention of those buyers because it mostly offers lower price than physical store with other side benefit. It also helps the customer to easily compare the price of the product and service. According to Sanjay and Nishant (2018), apparently the benefits of internet marketing are far more than the benefits of traditional marketing. Online marketing is a more efficient and faster way of directly reaching the buyer and is the ideal way for businesses to advertise locally or abroad. Furthermore, based on the study by [44], they indicate that the use of internet marketing will go beyond the boundaries and introduce the demographics of internet users with goods and services. Digital marketing is use extensionally by seller to market their product or service and by using the internet as the medium [17].

Corresponding Author: Syahirah Syuhada Sohibul Basr, School of Business Innovation and Technopreneurship, Universiti Malaysia Perlis, Malaysia 


\section{LITERATURE REVIEWS}

\section{Digital Marketing}

Digital marketing is a new form of marketing that appear in this technology era [4]. It is designed as a digital channel that help market a brand while providing patch for company to do business [4]. Digital advertising and marketing are one form of marketing being widely used to sell services or products and to reach consumers through using the usage of virtual channels [17]. The term "digital marketing" that describing the technique of the usage of virtual technologies to gather clients and build client preferences, sell brands, keep customers and increase sales has evolved over time from a specific term describing the advertising of services and products using virtual channels to an umbrella term [20]. According to [4], digital marketing and internet marketing are two different things with digital marketing using both online and offline technologies, while internet marketing only use technologies or online. Using these technologies, it also can assist the customer in gaining information for their buying activities [13]. Digital are believed can change the consumer behaviour toward the products, company, and brands [24]. The way marketer markets the product and the way in which the clients are shopping for the identical have been change with the introduction of digital marketing [45]. In the study by [42] stated that the barrier in the marketing industry are being break because of the expanding of digital marketing.

\section{Purchasing Behavior}

[45] stated that purchasing behaviour marketing is a process of establishing relationships between products offered in the market and targeted purchasing behaviour groups. Consumer behaviour is also defined as customer behaviour in purchasing, using, evaluating and classifying goods and services that are expected to meet their need [47]. [3], argue that consumer behaviour is the result of an emotional reaction and customers can create situations to purchase products or services. There are three independent factors influencing this emotional response: pleasure, stimulation, and dominance. A consumer behaviour understanding allows a marketer to take marketing decisions that are compatible with their consumer needs. Product type, prior purchase via the Internet and gender are the factor that have an effect on purchase intention [8]. According to [5], consumer buying behavior is a decision process in addition to an attitude of the people concerned in purchasing and using products. After recognizing a need or a want, clients start attempting to find products or services that fit their requirements. Behaviors are influenced by internal states and external factors [43] Attracting customers to an online company is very difficult because first the online company needs to convince customers to do online shopping, and then the customer will select a desired company from a large number of competitors. The online company therefore needs to establish effective customer relationships to be selected. Understanding consumer behaviour is a key to building such relationships [19].

\section{Attitude}

Attitude is the evaluation of performing a selected behaviour concerning the attitude item, which include buying the product [6]. Attitude describes how people are inclined to respond to an incentive [2]. Attitude was also found to be the most important factor affecting behavioral goals [5]. As indicated by [53], attitude is considered to be an important factor in impacting consumer intention in the purchase of products as those with strong positive attitudes seemed to have more intentions to buy the products. Attitude is assumed to be directly related to behavior of intent [53]. [24], noted that people tend to have attitudes toward things like politics, shopping, religion, food, music, etc. In addition, he elaborated in his study that it is the impact of attitudes that lets people put those things in a frame whether they like it or not. Attitude is taken into consideration as key idea on client conduct that become described as set of beliefs, revel in and emotions forming a predisposition to behave in a given direction [10]. Trust has been found to have a significant positive effect on the intention to use online shopping, according to [35]. It is also supported by [26] by saying that online purchasing online has a positive influence on trust. [54] supported the evidence that there are significant online buying behaviours or intentions of buying a particular product online with trusting sources of online information. [8], found confidence to be an important factor in influencing the intention of buying. It was also supported by [55] tested the impact of confidence on the adoption of online shopping and found a significant positive effect of confidence on the intention to buy online.

\section{Subjective Norms}

[2] stated that, while challenging and performing the identical, subjective norm can be stated as a form of perception that people approve or disapprove of certain behaviour. The subjective standard also provides them with information on the suitability of the behaviour under consideration while independently affecting purchase intention [26]. Subjective norms refer to the' perception of the person that most people who are important to him believe that the behaviour in question should or should not be carried out' [35]. Subjective standards are explained as social environment (social groups) influences on individuals affecting their 
behaviour or intentions [33]. Empirical studies have shown that family and friends ' social influence has an impact on buying intentions [53]. [20] also stressed the importance of mass media and external communication in influencing the intention toward a product that can be considered as part of social standards. Subjective norms contain the ideals of a person about the extent to which other people are affected by the assumption that the individual is or is no longer involved in the behaviour [24]. Subjective norms are determined by other people's perceived social pressure for an individual to act in a certain way and their motivation to comply with the views of those individuals. Before making a shopping decision, consumers tend to listen to verbal recommendations from close families and relatives, friends or even media. Therefore, in order to shift the perception of Malaysian consumers to e-stores, online retailers need to maximize efforts to promote and deliver good customer services to increase their interest in online shopping [27].

\section{Perceived Behaviour Control}

Perceived behavior control consists of the belief of one's own talents and sense of control over the situation and is described as an aggregate of locus of control and selfefficacy (perceived ability to carry out the challenge) [29]. Perceived behavioural control reflects beliefs regarding the access to resources and opportunities needed to perform a behavior [9]. [50] argues that perceived behavioural control can be conceptualized as the ability of individuals to control their behaviour and their level of trust in their ability to perform or not. Therefore, the belief of an individual will influence the behavioural intention of the individual and will encourage him / her to perform the target behaviour. As noted earlier, their level of confidence in performing the actual behaviour strongly influences the behavioural intention of people [50].

On the contrary, the finding by [23] found that perceived control of behaviour is still a significant predictor influencing intention. The study also confirms that perceived control of behaviour has a positive relationship which means that it is not unusual to have greater control impact in explaining variability in behaviour. It is determined by the beliefs of the individual about the power of both internal and situational factors to facilitate behaviour performance. The more control and individuals feel about making purchases of products, the more likely they are to do so [53. Behaviour control is specified in the form of selfefficacy as a condition in which people believe a behaviour is easy or difficult to do [51]. The perceived usefulness of the website commonly depends on the performance of technological traits which includes advanced search engines like google and the private carrier supplied via the service issuer to [23]. According to [23], perceived was proven to have significant impact on the intention to purchase via internet with various information and high-quality items' descriptions must be provided to the clients to assist customers in making an properly-informed decision.

\section{Pricing}

Price is the amount for which product, service or idea is exchanged, or offered for sale regardless of its really worth or value to potential [3]. The definition of prices policy is one of the most important management decisions, because it influences the profitability of companies and the competitiveness of the market. Price is one of the most flexible elements of the marketing mix, which at once and in the short term interferes with a company's profitability and price efficiency [8]. Price is one of the non-product attributes of brand associations where it can be a significant association in the formation of brand perceptions, especially in terms of value and desirability, and is a criterion by which consumers often segment their knowledge of a market or category [33]. Many consumers are willing to spend extra money if they have the perception that the product, they have purchased carries extra value. This value comes in the form of a better taste, a more creative design, and improved performance, an enhanced visual appeal or function [33]. Pricing strategy are varying to accommodate the different market and sector while classify the strategy into three type such as cost-based pricing, competition-based pricing and customer valuebased pricing [34]. Promoting prices is considered to be a very important marketing stimulus for motivating consumers and the feeling of anticipated regret by consumers is also an incentive to buy. When faced with price discounts, consumers are more likely to encourage purchasing behaviour. Since online shopping customers are often offered a better deal, they can get the same product at a lower price as they buy at the store [20]. Because online stores offer a variety of products and services to customers. It gives customers more opportunities to compare prices from different websites and find products at lower prices than purchases from local retail stores [20]. Some websites offer auction or best offer option to customers so that they can make a good deal for their product. It also makes shopping a real chance game and treasure hunt, making shopping a fun and entertainment [20].

\section{Theory of Planned Behaviour}

Theory of Planned Behaviour (TPB) is introduced by [2]. It is the extension of the Theory of Reasoned Action (TRA) which explains one's intention to form if the, behaviour of two factors: attitude and subjective norms. In 1988, Azjen added a new factor that was perceived as control of behaviour, and then called Planned Behaviour 
Theory [51]. TPB model provide a better explanation of behavioural model that a person is assumed to perform certain behaviour if that person has actual control over the behaviour [2]. Thus, when a person has a more favourable attitude and subjective norm, and with the acceralation of perceived behavioural control and intention, that particular person will perform the actual behaviour [2]. In TPB model, behavioural beliefs are expected to influence attitude, so as the effect of normative beliefs on the subjective norms while control beliefs constitute the foundation of behavioural control [54]. Attitude, subjective norms and perceived behavioural control are the differential pathways to behavioural intention outlined by the TPB [49].

\section{METHODOLOGY}

\section{Population and Sample}

This research use convenience sampling because the focus of data collection is only in Kangar area where it is near to the researcher place. The are no inclusive basis when asking the respondent to answer the question. For this research, we randomly selected 381 people out of 67,700 Kangar populations to be the respondents. The number of respondents is being determine by using the Krejcie and Morgan table [24a]. The target sample are given questionnaire that contains question about the independent variable, dependent variable and demographic factors. They are given time to answer the question. In the questionnaire, the demographic factors are being asked to identify and observe the respondent background. It also to analyze whether they aware of how the digital world work.

\section{Data Collecting Instrument}

The questionnaire is the main instrument of the data collection. The questionnaire is being divided into two section with section A are consist of the demographic question while section $\mathrm{B}$ are related to the independent variable and dependent variable. The questionnaire uses Likert Scale as a measure tool. Likert Scale with 5 point are used with option 1- Strongly Disagree, 2- Disagree, 3- Neutral, 4- Agree and 5- Strongly Agree [26a]. The respondent needs to respond to the question by choosing these options for each question. The questionnaires are being distributes using Google form and paperbased survey.

\begin{tabular}{|l|r|r|r|r|}
\hline Model & R & R Square & Adjusted R Square & $\begin{array}{c}\text { Std. Error of the } \\
\text { Estimate }\end{array}$ \\
\hline 1 & $.237^{\mathrm{a}}$ & .056 & .046 & 1.50644 \\
\hline
\end{tabular}

\begin{tabular}{|cc|c|c|c|c|c|}
\hline \multicolumn{2}{|c|}{ Model } & $\begin{array}{l}\text { Sum of } \\
\text { Squares }\end{array}$ & df & Mean Square & F & Sig. \\
\hline & Regression & 49.095 & 4 & 12.274 & 5.409 & $.000^{\mathrm{b}}$ \\
1 & Residual & 821.508 & 362 & 2.269 & & \\
& Total & 870.604 & 366 & & & \\
\hline
\end{tabular}

\begin{tabular}{|c|c|c|c|c|c|}
\hline \multirow[t]{2}{*}{ Model } & \multicolumn{2}{|c|}{$\begin{array}{l}\text { Unstandardized } \\
\text { Coefficients }\end{array}$} & \multirow{2}{*}{$\begin{array}{c}\text { Standardized } \\
\text { Coefficients } \\
\text { Beta }\end{array}$} & \multirow[t]{2}{*}{$\mathrm{t}$} & \multirow[t]{2}{*}{ Sig. } \\
\hline & B & Std. Error & & & \\
\hline (Constant) & 7.212 & .866 & & 8.328 & .000 \\
\hline Attitude & .282 & .083 & .252 & 3.380 & .001 \\
\hline Subjective & .145 & .060 & .147 & 2.407 & .017 \\
\hline Norms & & & & & .721 \\
\hline Perceived & .021 & .060 & .021 & .357 & \\
\hline $\begin{array}{l}\text { Behavior } \\
\text { Pricing }\end{array}$ & -.184 & .077 & -.181 & -2.377 & .018 \\
\hline
\end{tabular}


To accept the hypothesis made, the significant value of the variable must be lower than 0.05 in the regression analysis. This is to measure how strong the independent variable will affect the dependent variable. Based on the analysis done, out of the four variables, only perceive behavior control was found to have no significant effect on digital marketing with significantly higher than 0.05 with 0.721 . However, this cannot be indicated that there is no impact, but the effect maybe minimum to certain degree towards digital marketing. The factor that contributed to this result is because the consumers have control on themselves. They not easily sway with the marketing activity run and have their own mindset on the product and brand. This result also being support by another past researcher. In the research by [42], the finding of the study also shows that there are no relationship between perceived behavior control and digital marketing. Therefore, the hypothesis that is perceived behavior control has an impact towards digital marketing is rejected.

Next, the variable that will be discussed is attitude. Based on the significant value which is 0.01 argue that there is significant effect of attitude to the digital marketing. This indicates that the customers that have attitude behavior are easy to cajole. There also another factor where the customer has certain feeling or soft sport on the product or service. So, they unconsciously will attract to the colorful and interesting digital advertisement activity. This will bring desire to the buyers to purchase the certain product. So, from the hypothesis, attitude has an impact on the digital marketing.

The third variable is subjective norms. There is relationship between subjective norms and digital marketing with significant value to 0.017. Consumers with this purchasing behavior are depending on other opinion and input before making a certain decision. This indirectly exposed them to the digital advertisement activity. Even if the buyers are not the Internet user, they may be influence by the family and friend who is the user of the technology. Another factor that may affect the purchasing is viral marketing. Now, if the advertisement is being circulate, the people will unintentionally draw attention to the product. Thus, the hypothesis is being accepted.

The last variable is pricing. The significant value shows that there is a relationship between pricing and digital marketing with value 0.018 . Consumer attraction toward price is high. Markdown price or promotion price can be a catalyst for customers to buy. Marketer will be planted concept of regret to customer and encouraged them to purchase the product. Digital marketing usually offer price lower than the physical store to appeal to the potential buyers. This being support by [20], as they state that online shopping customers are often offered a better deal, they can get the same product at a lower price as they buy at the store. Hence, the last hypothesis where pricing have an impact on digital marketing is accepted.

\section{CONCLUSIONS}

This study, which is of an investigative and conceptual nature, offers a variety of options for future studies, both in terms of development of hypothesis and approval of concept. In fact, more studies will be needed to refine the findings and further elaborate them. The empirical findings answer the research questions of the study and help achieve its goals. These results have a few significant implications in both evaluating and developing the variable. This study creates an opportunity to modify and justify the theories and constructs emerging from the analysis. For example, further analysis of why the perceived behavior control variable is not compatible with the dependent variable will be required. One could also enquire if and in what extent different variable and theory can be identified than can be used to build many frameworks. This study will provide these researchers with valuable information when selecting the variable in the future.

\section{REFERENCES}

[1] Ahmad Bilal Khilji. (2016). The Influence of Attitude on Online Buying Behaviour and Moderator Impact of Culture: A Study of Islamic Republic of Pakistan Youth. Pakistan Journal of Engineering, Technology \& Science, 2(1).

[2] Ajzen, I., Brown, T. C., \& Carvajal, F. (2004). Explaining the discrepancy between intentions and actions: The case of hypothetical bias in contingent valuation. Personality and Social Psychology Bulletin, 30(9), 1108-1121.

[3] Alfred, O. (2013). Influences of Price and Quality on Consumer Purchase of Mobile Phone In The Kumasi Metropolis In Ghana A Comparative Study. European Journal of Business and Management, 5(1).

[4] Anjali. (2017). A Study On Impact Of Digital Marketing On Customer Buying Behavior. International Journal of Emerging Issues In Management And Technology, 7(2). [5] Asamoah, E. S., \& Chovancová, M. (2011). The influence of price endings on consumer behaviour: an application of the psychology of perception. Acta Universitatis Agriculturae et Silviculturae Mendelianae Brunensis, 59(7), 29-38.

[6] Bastam, H., Lotfabadi, V., Kouchakzadeh, V., \& Faraji, M. (2017). A Study of Factors Affecting Consumer Buying Behaviour in Online Shopping 
(Case Study: Digikala Online Store). International Journal of Business and Technopreneurship, 7(3).

[7] Bee, E., \& Selvan, P. (2015). Application of the Theory of Planned Behaviour on impulse buying behaviour in an internationalized shopping centre. - Sunway Institutional Repository. Sunway University Business School.

[8] Benachenhou Sidi Mohammed, Arzi Fethi, \& Omar Belkhir Djaoued. (2017). The Influence of Attitude, Subjective Norms and Perceived Behavior Control on Entrepreneurial Intentions: Case of Algerian Students. American Journal of Economics, 7(6), 274-282.

[9] Buhmann, A., \& Brønn, P. S. (2018). Applying Ajzen's theory of planned behavior to predict practitioners' intentions to measure and evaluate communication outcomes. Corporate Communications: An International Journal, 23(3), 377-391.

[10] Durmaz, Y. (2013). The Influence of Social Factors On Consumer Buying Behaviour And An Application In Turkey. Journal of Social Science Research, 2(2), 256-263.

[11] Fagan, A. (2014). Pricing practices: A critical review of their effects on consumer perceptions and behaviour. Journal of Retailing and Consumer Services, 21(5), 696-707.

[12] Gabriel, J., \& Kolapo, S. (2015). Online Marketing and Consumer Purchase Behaviour: A Study of Nigerian Firms. British Journal of Marketing Studies, 3(7), 1-14. [13] George, J. F. (2004). The theory of planned behavior and Internet purchasing. Internet Research, 14(3), 198-212.

[14] Gerpott T. J. (2016). A review of the empirical literature on Pay-What-You-Want price setting. Management \& Marketing, Sciendo, vol. 11(4), pages 566-596

[15] Hackman, C., \& Knowlden, A. (2014). Theory of reasoned action and theory of planned behaviorbased dietary interventions in adolescents and young adults: a systematic review. Adolescent Health, Medicine and Therapeutics, 101.

[16] Higuchi, A., Dávalos, J., \& Hernani-Merino, M. (2017). Theory of planned behavior applied to fish consumption in modern Metropolitan Lima. Food Science and Technology, 37(2), 202-208. [17] Huck, S., \& Wallace, B. (2015). The impact of price frames on consumer decision making: Experimental evidence.

[18] Iftikhar, F., \& Khan, I. (2017). The Impact of Email Marketing, Mobile Marketing and Retargeting on Online $\mathrm{h}$ Consumer Buying Behavior.

[19] Ingenbleek, P. T. M., \& van der Lans, I. A. (2013). Relating price strategies and price-setting practices. European Journal of Marketing, 47(1/2), 27-48.
[20] Katawetawaraks, C., \& Wang, C. L. (2011). Online Shopper Behavior: Influences of Online Shopping Decision. Asian Journal of Business Research, 1(2).

[21] Ketabi, S. N., Ranjbarian, B., \& Ansari, A. (2014a). Analysis of the Effective Factors on Online Purchase Intention through Theory of Planned Behavior. International Journal of Academic Research in Business and Social Sciences, 4(4).

[22] Khandelwal, U., \& Bajpai, N. (2013). Measuring Consumer Attitude through Marketing Dimensions: A Comparative Study between Metro and Non-metro Cities. Jindal Journal of Business Research, 2(2), 85-103.

[23] Kim, M. S., \& James, J. (2016). The theory of planned behaviour and intention of purchase sport team licensed merchandise. Sport, Business and Management: An International Journal, 6(2), 228243.

[24] Kim-Soon, N., Rahman, A., \& Ibrahim, N. (2016). Theory of Planned Behavior: Undergraduates' Entrepreneurial Motivation and Entrepreneurship Career Intention at a Public University. Journal of Entrepreneurship: Research \& Practice, 2016.

[24a] Krejcie, R. V., \& Morgan, D. W. (1970). Determining sample size for research activities. Educational and psychological measurement, 30(3), 607-610.

[25] Kukar-Kinney, M., Ridgway, N. M., \& Monroe, K. B. (2012). The Role of Price in the Behavior and Purchase Decisions of Compulsive Buyers. Journal of Retailing, 88(1), 63-71.

[26] Kumar, B., Manrai, A. K., \& Manrai, L. A. (2017). Purchasing behaviour for environmentally sustainable products: A conceptual framework and empirical study. Journal of Retailing and Consumer Services, 34, 1-9.

[26a] Likert, R. (1932). A technique for the measurement of attitudes. Archives of psychology.

[27] Lim, Y. J., Abdullah, O., Shahrul, N. S., Abdul, R. R., \& Safizal, A. (2016). Factors Influencing Online Shopping Behavior: The Mediating Role of Purchase Intention. Procedia Economics and Finance, 35, 401-410.

[28] Lodhi, S., \& Shoaib, M. (2017). "Impact of EMarketing on Consumer Behaviour: a Case of Karachi, Pakistan.” IOSR Journal of Business and Management, 19(01), 90-101.

[29] Mahalaxmi, M., \& Ranjith, P. (2016). A Study on Impact of Digital Marketing in Customer Purchase Decision in Trichy. IJIRST -International Journal for Innovative Research in Science \& Technology|, 2(10).

[30] McLaughlin, C., \& Stephans, S. (2019). The theory of planned behavior: the social media intentions of 
SMEs. Conference: Irish Academy of Management.

[31] Minton, E. A., Spielmann, N., Kahle, L. R., \& Kim, C.-H. (2018). The subjective norms of sustainable consumption: A cross-cultural exploration. Journal of Business Research, 82, 400-408.

[32] Moreno, F. M., Lafuente, J. G., Carreón, F. Á., \& Moreno, S. M. (2017). The Characterization of the Millennials and Their Buying Behavior. International Journal of Marketing Studies, 9(5), 135.

[33] Muhammed, A., \& Selvan, P. (2018). How Does Green Products? Price and Availability Impact Malaysians? Green Purchasing Behavior? The Journal of Social Sciences Research, 4(3), 28- 34.

[34] Nguyen, T. N., Phan, T. T. H., \& Vu, P. A. (2015). The Impact of Marketing Mix Elements on Food Buying Behavior: A Study of Supermarket Consumers in Vietnam. International Journal of Business and Management, 10(10).

[35] Nurul, A. H., Abdullah, O., Safizal, A., Shahrul, N. S., Nor, F. R., \& Hazalina, M. S. (2016). The Relationship of Attitude, Subjective Norm and Website Usability on Consumer Intention to Purchase Online: An Evidence of Malaysian Youth. Procedia Economics and Finance, 35, 493502.

[36] Pande, A. (2015). Role of consumer attitudes, beliefs and subjective norms as predictors of purchase behaviour: a study on personal care purchases. The Business \& Management Review, 5(4).

[37] Passingham, J., \& Battinson, N. (1991). The Green consumer revelation: How the availability of environmentally friendly products has really affected household purchasing patterns. Management Research News, 14(4/5), 17-19.

[38] Pawar, S., \& Naranje, S. (2015). "A Study on Factors Influencing on Buying Behaviour of Customers."

[39] Ramona Mihaela Urziceanu, \& ValentinaSimona Pașcalău. (2016). The purchase behavior of the consumer. Agora International Journal of Economical Sciences, 10(0), 41-44.

[40] Rapaccini, M. (2015). Pricing strategies of service offerings in manufacturing companies: a literature review and empirical investigation. Production Planning \& Control, 26(14-15), 1247- 1263.

[41] Raygor, A. (2016). The Theory of Planned Behavior: Understanding Consumer Intentions to Purchase Local Food in Iowa.

[42] Reddy, G. (2017). Digital marketing impact on the consumer decision making process in Nike's customer retail operations in South Africa. University of Van Pretoria.
[43] Roth, S., \& Bösener, K. (2014). The influence of customer satisfaction on customer price behavior: literature review and identification of research gaps. Management Review Quarterly, 65(1), 1-33.

[44] Saraih, U. N., Zin Aris, A. Z., Abdul Mutalib, S., Tunku Ahmad, T. S., \& Amlus, M. H. (2018). Examining The Relationships between Attitude Towards Behaviour, Subjective Norms and Entrepreneurial Intention among Engineering Students. MATEC Web of Conferences, 150, 05011.

[45] Sivasankaran, S. (2017). Digital Marketing and Its Impact on Buying Behaviour of Youth (Special Reference to Kanyakumari District). International Journal of Research in Management \& Business Studies, 4(3).

[46] Smith, A. (2015). Attitude, Subjective Norm, and Perceived Behavioral Control as Indicators for Nurse Educators' Intention to Use Critical Thinking Teaching Strategies: a Structural Equation Model Analysis.

[47] Shamount, M. D. (2016). The Impact of Promotional Tools on Consumer Buying Behavior in Retail Market. International Journal of Business and Social Science, 7(1).

[48] Spáčil, V. and Teichmannová, A. (2016). Intergenerational Analysis of Consumer Behaviour on the Beer Market. Procedia - Social and Behavioral Sciences, 220, pp.487-495. [49] Sommer, L. (2011). The Theory Of Planned Behaviour And The Impact Of Past Behaviour. International Business \& Economics Research Journal (IBER), 10(1).

[50] Torbati, E., Asadi, R., \& Mohammadzadeh, F. (2017). Introducing A Consumer Behavior for Buying Luxury Goods Based on The Theory of Planned Behavior. International Journal of Economics, Commerce and Management United Kingdom, 6(6).

[51] Utami, C. (2017). Attitude, Subjective Norms, Perceived Behavior, Entrepreneurship Education and Self-efficacy toward Entrepreneurial Intention University Student in Indonesia. European Research Studies Journal, XX(2A).

[52] Victor, V., Joy Thoppan, J., Jeyakumar Nathan, R., \& Farkas Maria, F. (2018). Factors Influencing Consumer Behavior and Prospective Purchase Decisions in a Dynamic Pricing Environment-An Exploratory Factor Analysis Approach. Social Sciences, 7(9), 153.

[53] Wong, S.-L., Hsu, C.-C., \& Chen, H.-S. (2018). To Buy or Not to Buy? Consumer Attitudes and Purchase Intentions for Suboptimal Food. International Journal of Environmental Research and Public Health, 15(7), 1431.

[54] Yang, H., Zhang, D., \& Zhang, C. (2017). The influence of reference effect on pricing strategies 
in revenue management settings. International Transactions in Operational Research, 24(4), 907924.

[55] Yilmaz, K. G., \& Belbag, S. (2016). Prediction of Consumer Behavior Regarding Purchasing Remanufactured Products: A Logistics Regression
Model. International Journal of Business and Social Research, 6(2), 01.

[56] Zhou, H., \& Gu, Z. (2015). The Effect of Different Price Presentations on Consumer Impulse Buying Behavior: The Role of Anticipated Regret. American Journal of Industrial and Business Management, 05(01), 27-36. 